\title{
LINE-1 ORF1 Protein Is Up-regulated by Reactive Oxygen Species and Associated with Bladder Urothelial Carcinoma Progression
}

\author{
PATCHARAWALAI WHONGSIRI ${ }^{1}$, CHAOWAT PIMRATANA ${ }^{2}$, UDOMSAK WIJITSETTAKUL ${ }^{2}$, \\ DEPICHA JINDATIP ${ }^{3}$, ANAPAT SANPAVAT ${ }^{4}$, WOLFGANG A. SCHULZ ${ }^{5}$, \\ MICHÈLE J. HOFFMANN ${ }^{5}$, WOLFGANG GOERING ${ }^{6}$ and CHANCHAI BOONLA ${ }^{1}$ \\ Departments of ${ }^{1}$ Biochemistry, ${ }^{3}$ Anatomy and ${ }^{4}$ Pathology, Faculty of Medicine, \\ Chulalongkorn University, Bangkok, Thailand; \\ ${ }^{2}$ Division of Urology, Buriram Hospital, Buriram, Thailand; \\ Departments of ${ }^{5}$ Urology and ${ }^{6}$ Pathology, Medical Faculty, \\ Heinrich-Heine-University Düsseldorf, Düsseldorf, Germany
}

\begin{abstract}
Background/Aim: Reactivation of long interspersed nuclear element-1 (LINE-1) and oxidative stress are suggested to have oncogenic potential to drive tumorigenesis and cancer progression. We previously demonstrated that reactive oxygen species (ROS) caused hypomethylation of LINE-1 elements in bladder cancer cells. In this study, we investigated the expression of LINE-1-encoded protein (ORF 1p) and oxidative stress marker 4-hydroxynonenal (4-HNE) in human bladder cancer tissues, as well as induction of ORF1p expression by ROS in bladder cancer cell lines. Materials and Methods: Thirty-six cancerous and 15 non-cancerous adjacent tissues were immunohistochemically stained for ORF1p and 4-HNE. ORF1p expression and cell migration were determined in bladder cancer cells exposed to $\mathrm{H}_{2} \mathrm{O}_{2}$. Results: ORF1p and 4HNE expression was higher in cancerous than non-cancerous tissues. Elevated ORF1p expression was associated with increased 4-HNE expression and with advanced tumors. $\mathrm{H}_{2} \mathrm{O}_{2}$ provoked oxidative stress and up-regulated ORF1p expression in VM-CUB-1 compared to the untreated control, and to a lesser degree in TCCSUP. $\mathrm{H}_{2} \mathrm{O}_{2}$ exposure enhanced cell migration in UM-UC-3, TCCSUP and VM-CUB-1. Conclusion: Elevated ORF1p expression is associated with
\end{abstract}

This article is freely accessible online.

Correspondence to: Chanchai Boonla, Ph.D., Assistant Professor, Department of Biochemistry, Faculty of Medicine, Chulalongkorn University, Bangkok 10330, Thailand. Tel/Fax: +66 22564482, email: chanchai.b@chula.ac.th

Key Words: LINE-1, bladder cancer, immunohistochemistry, ORF1p, 4-HNE, oxidative stress, cancer progression. tumor progression. ROS experimentally induce ORF1p expression and promote migration in bladder cancer cells.

Retrotransposon reactivation is well recognized to contribute to tumor development and progression. With over 500,000 copies Long Interspersed Nuclear Element-1 (LINE-1) is the predominant non-LTR retrotransposon in the human genome comprising approx. $17 \%$ of DNA (1). Whereas the majority of LINE-1 elements (>99.8\%) are 5'-truncated or rearranged and lack retrotransposition activity (2), a relatively small number of full-length autonomous LINE-1 elements, $6 \mathrm{~kb}$ in length encode ORF1p and ORF2p proteins and are responsible for LINE-1 mobilization. In particular, retrotransposition events in the germline and in cancers are executed by around 100 active retrotransposition-competent 'hot' LINE-1 elements with intact ORF1p and ORF2p (2, 3). Increased LINE-1 activity and LINE-1 retrotransposition are strongly linked to carcinogenesis and tumor progression $(4,5)$.

The ORF1p (40 kDa) forms homotrimers binding and chaperoning LINE-1 transcripts and possibly other RNA species. ORF2p (150 kDa) exerts dual enzymatic activities as an endonuclease and reverse transcriptase. ORF2p is commonly expressed at a very much lower level than ORF1p (6). Aberrant expression of ORF1p is suggested to be a hallmark of epithelial cancer and could be a new biomarker of neoplasia $(7,8)$. Mechanistic insight into how ORF1p is up-regulated in tumors is largely lacking. Loss of epigenetic silencing by DNA methylation is the most widely studied mechanism of LINE-1 dysregulation in cancers, and LINE-1 promoter hypomethylation is associated with the development of many cancers, including urothelial cancer (9).

Urothelial carcinoma is a common urological cancer with the highest rate of recurrence among malignancies (10). 
Widespread hypomethylation of LINE-1 in bladder tumors was first reported by Jürgens et al. in 1996 (11), and later confirmed by Florl et al. (12) and Chalitchagorn et al. (13). Full-length LINE- 1 transcripts can be detected in bladder cancer cell lines, and it was suggested that the LINE-1 transcript expression was related to LINE-1 hypomethylation (12). However, the cause of LINE-1 hypomethylation in bladder cancer is not fully known. Recently, we reported an association of increased oxidative stress with LINE-1 hypomethylation in bladder cancer patients (14), and demonstrated in bladder cancer cells that oxidative stress induced by reactive oxygen species (ROS) was a cause of LINE-1 hypomethylation $(15,16)$. We hypothesize that hypomethylation of LINE-1 induced by ROS in bladder cancer would lead to genomic instability and cancer progression through mobilization of LINE-1 elements. To date, expression and role of LINE-1-encoded proteins in bladder cancer have rarely been explored.

In this study, we investigated the expression and clinical relevance of ORF1p in bladder cancer tissues using immunohistochemical staining and its relation to the oxidative stress marker 4-hydroxynonenal (4-HNE). Furthermore, we investigated whether ROS are capable of inducing ORF1p expression and influencing cell migration in bladder cancer cell lines.

\section{Materials and Methods}

Patients and paraffin-embedded tissues. Bladder tissue specimens (36 tumor and 15 non-cancerous adjacent tissues) were collected during surgery from histologically-proved bladder cancer patients (by C.P. and U.W.), and fixed in $10 \%$ buffered formalin. The demographic and basic clinical data of the patients are detailed in Table I. Briefly, a total of 36 patients histologically diagnosed with urothelial carcinoma were included in this study consisting of 31 $(86.1 \%)$ men and $5(13.9 \%)$ women. Mean age of the patients was $71.5 \pm 13.3$ years. About one-third of the patients $(11 / 36,30.6 \%)$ presented with recurrent tumors. Transurethral resection of the bladder tumor $(88.6 \%)$ was the main surgical procedure for tumor removal. Thirty-two and 33 cases had available data of tumor stage and histological grading, respectively. For further analysis, tumors were classified as papillary/non muscle-invasive $(19 / 32,59.4 \%)$ or muscle-invasive $(13 / 33,40.6 \%)$. Papillary urothelial neoplasm of low malignant potential (PUNLMP), low-grade tumor and highgrade tumors accounted for $2(6.1 \%), 13(39.4 \%)$ and $18(54.5 \%)$ cases, respectively (Table I). Tissue specimens were processed and paraffin blocks were sectioned into $3 \mu \mathrm{m}$ slices.

Ethics approval and consent to participate. All procedures performed in studies involving human participants were in accordance with the ethical standards of the institutional committee and with the 1964 Helsinki declaration and its later amendments or comparable ethical standards. Informed consent was obtained from all individual participants included in the study. The research protocol was reviewed and approved by the institutional Ethics Committee (IRB), Faculty of Medicine, Chulalongkorn University, Bangkok, Thailand.
Table I. Characteristics of studied bladder cancer patients.

\begin{tabular}{lc}
\hline Characteristic & Frequency $(\%)$ \\
\hline n 36 & \\
Age (years, mean \pm SD) & $71.5 \pm 13.3$ \\
Gender M:F (\%) & $31(86.1): 5(13.9)$ \\
Recurrence tumor $(\%)$ & $25(69.4)$ \\
No & $11(30.6)$ \\
Yes & $31(88.6)$ \\
Surgical approach (n=35) & $4(11.4)$ \\
TUR-BT & \\
Radical cystectomy & $19(59.4)$ \\
Tumor type (n=32) & $13(40.6)$ \\
Papillary/non muscle-invasive & \\
Muscle-invasive & $2(6.1)$ \\
Tumor grading (n=33) & $13(39.4)$ \\
PUNLMP & $18(54.5)$ \\
Low-grade &
\end{tabular}

TUR-BT: Transurethral resection of bladder tumor, PUNLUMP: papillary urothelial neoplasm of low malignant potential.

Immunohistochemical (IHC) staining. To immunostain ORF1p and 4-HNE in the paraffin-embedded bladder tumor sections, following deparaffinization and rehydration, heat-induced antigen retrieval was performed in sodium citrate buffer $(\mathrm{pH}$ 6.0). Sections were submerged in $0.3 \% \mathrm{H}_{2} \mathrm{O}_{2}$ in methanol for $30 \mathrm{~min}$ to inactivate endogenous peroxidase and non-specific binding was blocked with normal horse serum for $20 \mathrm{~min}$ at room temperature. Sections were then incubated with 1:20,000 mouse ORF1p antibody (kindly donated by Prof. Kathleen H. Burns (8)) or 1:2,000 rabbit 4-HNE antibody (ab46545, abcam) at $4^{\circ} \mathrm{C}$, overnight. After washing, sections were incubated with biotinylated universal antibody for 1 $\mathrm{h}$, followed by $\mathrm{ABC}$ reagent for $30 \mathrm{~min}$ (Vectastain Elite $\mathrm{ABC}$ Universal Kit). Immunostaining was visualized using diaminobenzidine (ImmPACT ${ }^{\mathrm{TM}}$ DAB Peroxidase Substrate Kit), sections were counterstained with Hematoxylin, dehydrated, cleared and mounted. Hematoxylin and eosin (H\&E) staining was performed according to the standard procedure.

Relative levels of ORF1p and 4-HNE expression were evaluated based on the percentage of positive cells $(0-5 \%=0,6-25 \%=1,26-$ $50 \%=2,51-75 \%=3$ and $75-100 \%=4)$ and intensity of staining (negative $=0,+=1,++=2,+++=3$ and $++++=4$ ), averaged from 5 different microscopic fields. IHC score was calculated from: score of $\%$ positive cells $(0-4) \times$ score of intensity (0-4), i.e. minimum score was 0 and maximum score was 16 . H\&E evaluation (by A.S.) was carried out to classify tumors as papillary/non muscle-invasive or muscle-invasive, and tumor grading into PUNLMP, low-grade and high-grade tumors.

Cell culture. VM-CUB-1, TCCSUP and UM-UC-3 cells were maintained in Dulbecco's modified Eagle's medium (DMEM) supplemented with $10 \%$ fetal bovine serum (FBS) (Gibco), $1 \%$ penstrep under $37^{\circ} \mathrm{C}, 5 \% \mathrm{CO}_{2}$, and $100 \%$ humidity. $\mathrm{H}_{2} \mathrm{O}_{2}$ (Sigma) was used to stimulate oxidative stress in the cells (for $72 \mathrm{~h}$ ) at sub-lethal doses, $30 \mu \mathrm{M}$ for VM-CUB-1 and $20 \mu \mathrm{M}$ for TCCSUP and UMUC-3, previously determined by MTT assay (data not shown). 


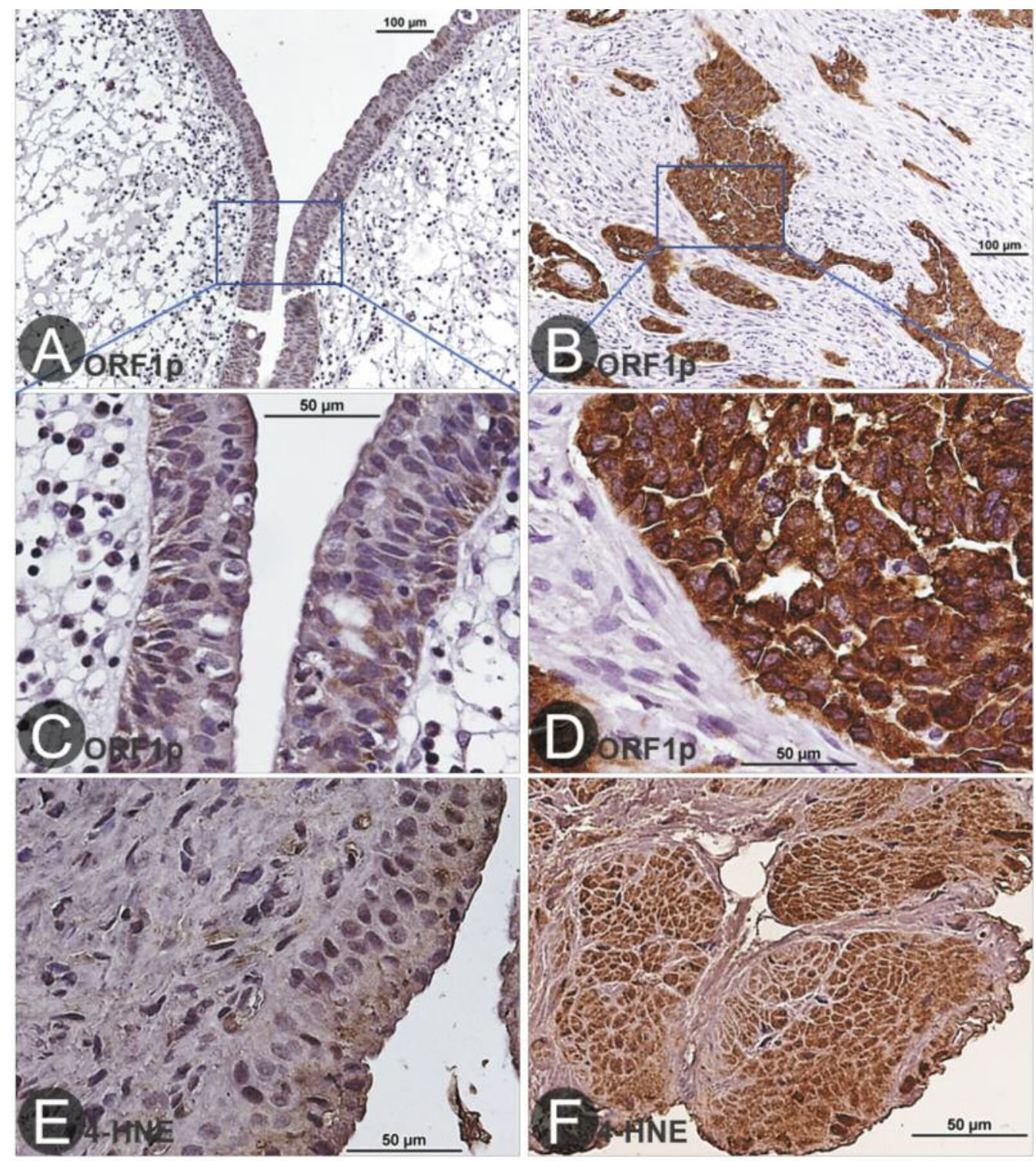

Figure 1. Representative micrographs of ORF1p and 4-HNE expression in bladder cancer tissues. ORF1p was negative or expressed at very low levels in non-cancerous bladder tissues ( $A$ and $C$ ). In contrast, expression of ORF1p in bladder cancer tissues was remarkably increased $(B$ and $D)$. Similar to ORF1p, 4-HNE expression was elevated in bladder cancer tissues $(F)$, but it was obviously low in non-cancerous bladder tissues (E). Magnifications: $\times 100(A$ and B),$\times 400(C-F)$.

Tocopheryl acetate (TA, at $300 \mu \mathrm{M})$ and S-adenosylmethionine $(\mathrm{SAM}$, at $100 \mu \mathrm{M})(17)$ were used as antioxidants for attenuating oxidative stress in the $\mathrm{H}_{2} \mathrm{O}_{2}$-treated cells (18).

Western blot and immunodetection. Cells were lysed with RIPA buffer (incubated on ice for 30 min with interval mixing every $10 \mathrm{~min}$ ), the lysate was centrifuged at $12,000 \times \mathrm{g}\left(4^{\circ} \mathrm{C}\right)$ for $5 \mathrm{~min}$ and the supernatant was collected. Protein concentration was determined using bicinchoninic acid assay. Total protein of $15 \mu \mathrm{g}$ was loaded for SDS-PAGE (10\% gel, $180 \mathrm{~V}$ for $1.5 \mathrm{~h}$ ).

The electrophoresed proteins were transferred to PVDF membrane (wet tank, $180 \mathrm{~mA}$ for $1 \mathrm{~h}$ ). After washing, membranes were blocked with $5 \%$ skimmed milk in TBST for 1 $\mathrm{h}$ at room temperature. The blots were then incubated with ORF1p antibody $(1: 10,000)$ overnight at $4^{\circ} \mathrm{C}$. After washing, blots were incubated with HRP-conjugated anti mouse antibody $(1: 5,000)$ at room temperature for $1 \mathrm{~h}$. Specific immunocomplexes were detected by developing in ECL reagent (SuperSignal ${ }^{\circledR}$ West Femto Maximum Sensitivity Substrate). Images of ECL signals were acquired and the band intensities were quantified by digital ECL scanner (LI-COR). As loading control, rabbit anti $\alpha$-tubulin antibody $(1: 20,000)$ was re-probed after stripping. Relative expression of ORF1p was normalized to $\alpha$-tubulin expression. 
Wound healing (scratch) assay. VM-CUB-1, TCCSUP and UM-UC$3\left(5 \times 10^{6}\right.$ cells per well) were seeded in 6-well plates and incubated for $24 \mathrm{~h}$ at $37^{\circ} \mathrm{C}, 5 \% \mathrm{CO}_{2}$ and $100 \%$ humidity. After creating a scratch (straight line) with a p200 pipette tip and washing twice with PBS, cells were treated in serum-free DMEM for $72 \mathrm{~h}$ as follows: untreated control, $\mathrm{H}_{2} \mathrm{O}_{2}$ or $\mathrm{H}_{2} \mathrm{O}_{2}+\mathrm{TA}$. Images of the scratch were acquired at the beginning $(0 \mathrm{~h})$ and the end $(72 \mathrm{~h})$ of treatments to compare the rate of gap closing, reflecting cell migration capability. Based on our experiences, VM-CUB-1 cells usually move much faster than UM-UC-3 and TCCSUP cells. We, therefore, monitored the migration of VM-CUB- 1 cells at $6 \mathrm{~h}$ after the $\mathrm{H}_{2} \mathrm{O}_{2}$ treatment.

Statistical analysis. Data are presented as mean \pm standard deviation (SD) or median (interquartile range, IQR) as appropriate. Twosample $t$-test or Mann-Whitney test was used to test the difference between two independent groups. Spearman rank correlation test was used for correlation analysis. Odds ratios (OR) were calculated from logistic regression. Stata version 12 and GraphPad Prism 5 were employed for graphs and statistical analyses. $p$-Value $<0.05$ was considered statistically significant.

\section{Results}

ORF1p expression and 4-HNE are increased in bladder tumor tissues. Expression of ORF1p was markedly increased in bladder cancer tissues compared with adjacent noncancerous bladder tissues (Figure 1A-D), most prominently in the cytoplasm of carcinoma cells. The IHC score for expression of ORF1p was significantly higher in bladder cancer tissues $(\mathrm{n}=33)$ than in non-cancerous bladder tissues $(\mathrm{n}=15)(p=0.026$, Figure 2A). The result clearly indicated that LINE-1 was reactivated in bladder cancer tissues.

4-HNE was increased in the bladder cancer tissues compared with the non-tumorous tissue (Figure 1E and F). Similar to ORF1p, 4-HNE was mainly detectable in the cytoplasm of cancer cells. The IHC score of 4-HNE was significantly greater in bladder cancer tissues $(\mathrm{n}=34)$ than in non-cancerous tissues $(\mathrm{n}=14)(p=0.0321$, Figure 2B) indicating that bladder cancer tissues experience increased oxidative stress.

We additionally analyzed the expression of ORF1p and 4-HNE specifically in cancerous and non-cancerous areas of paired bladder tissue samples. Expression of ORF1p in cancerous regions was significantly higher than in their noncancerous counterparts $(\mathrm{n}=12) \quad(p=0.0466$, Figure 2C). Likewise, 4-HNE was increased in cancerous regions compared to corresponding non-cancerous regions $(n=11)$ $(p=0.0183$, Figure 2D). Further, ORF1p expression and 4-HNE levels in bladder cancer tissues $(n=33)$ were well correlated indicated by a highly significant positive correlation (Spearman's rho $=0.6275, p<0.001$ ) (Figure 2E). We conclude that increased LINE-1 reactivation is associated with increased oxidative stress in bladder cancer tissues.

Increased ORFIp expression is associated with bladder tumor progression. Expression of ORF1p was significantly stronger
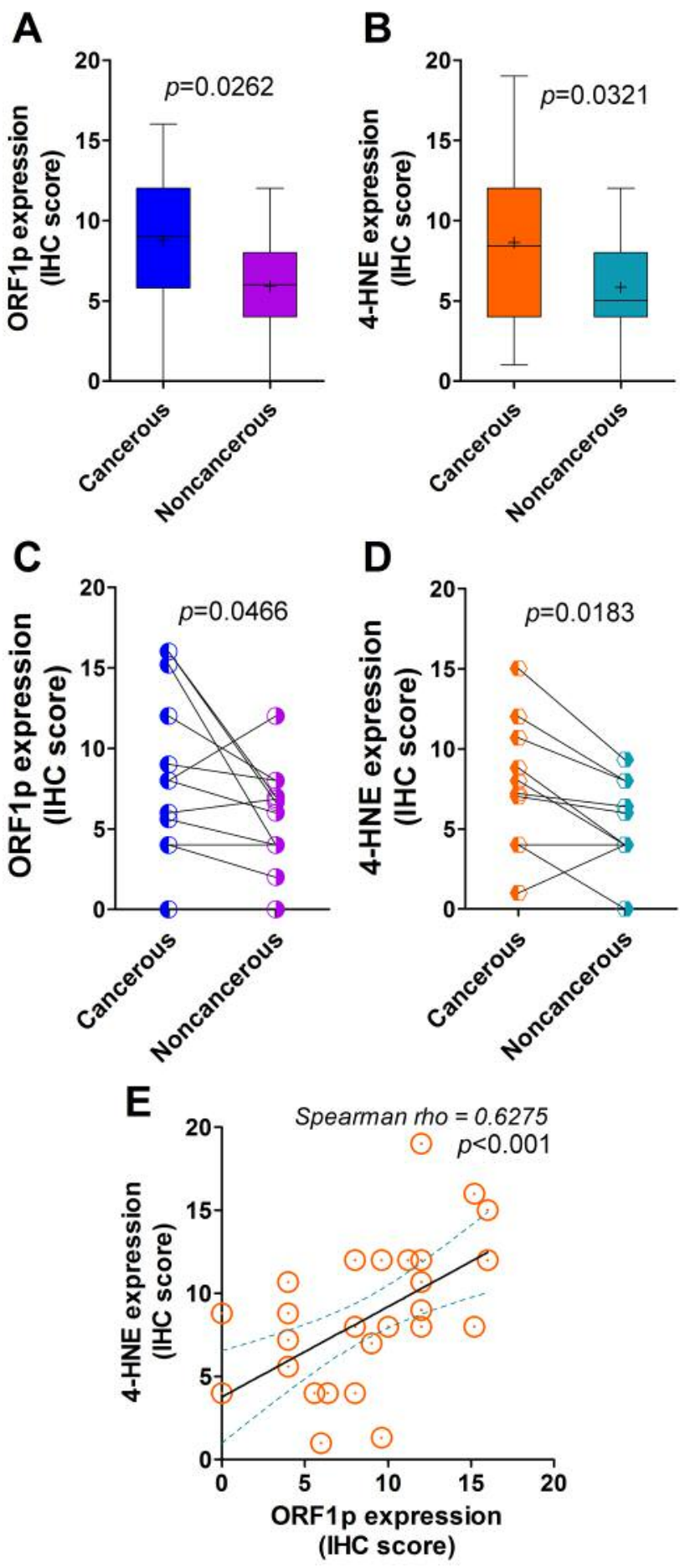

Figure 2. Levels of ORF1p and 4-HNE expression compared between cancerous and non-cancerous bladder tissues, and correlation of ORF1p and 4-HNE expression in bladder cancer tissues. Both ORF1p expression (A) and 4-HNE (B) levels were significantly higher in bladder cancer tissues than in non-cancerous bladder tissues. In paired cancerous and non-cancerous tissue samples, significantly higher levels of ORF1p (C) and 4-HNE $(D)$ expression were observed in cancerous areas compared to adjacent non-cancerous regions. ORF1p expression was positively correlated with 4-HNE expression in bladder cancer tissues $(E)$. 
A
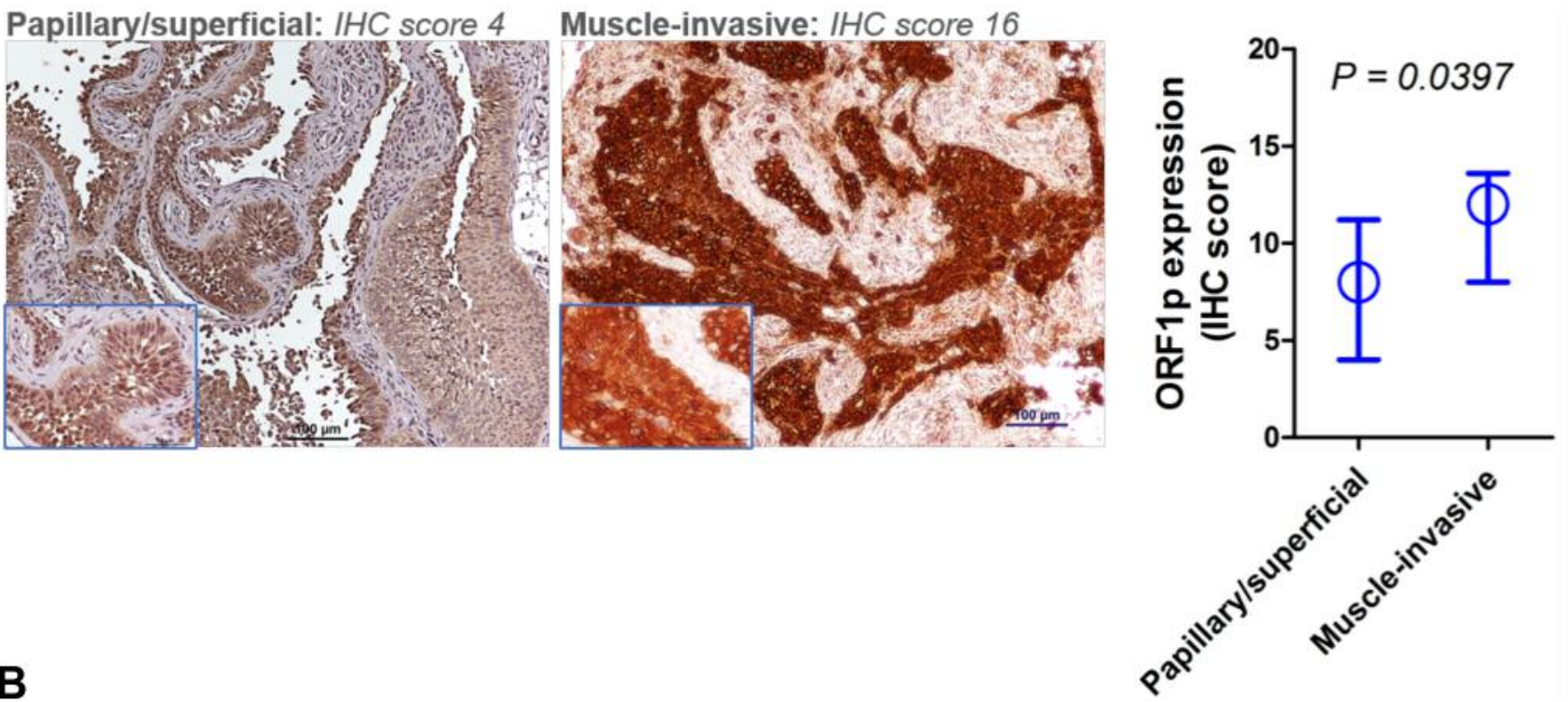

B

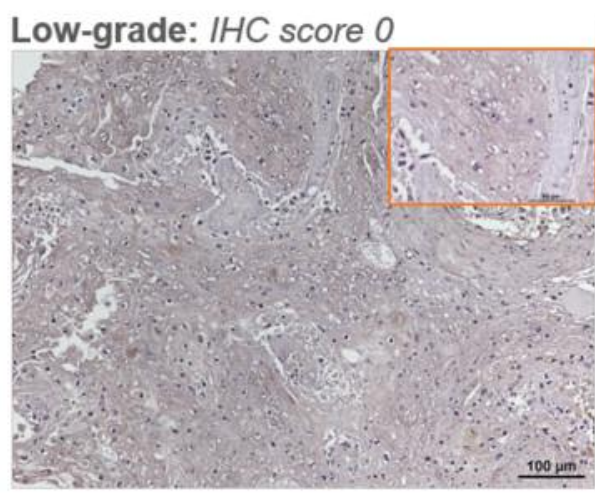

High-grade: IHC score 15.2

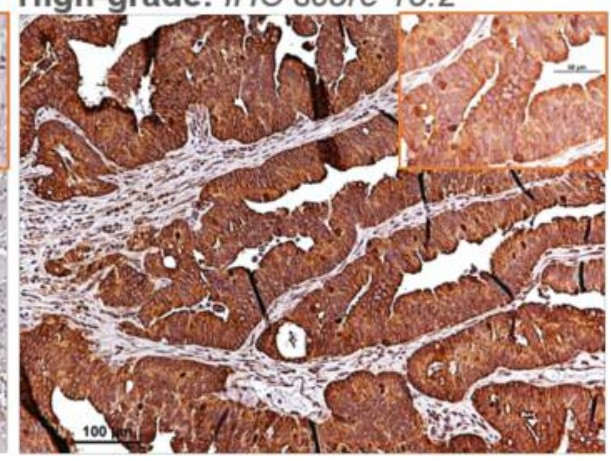

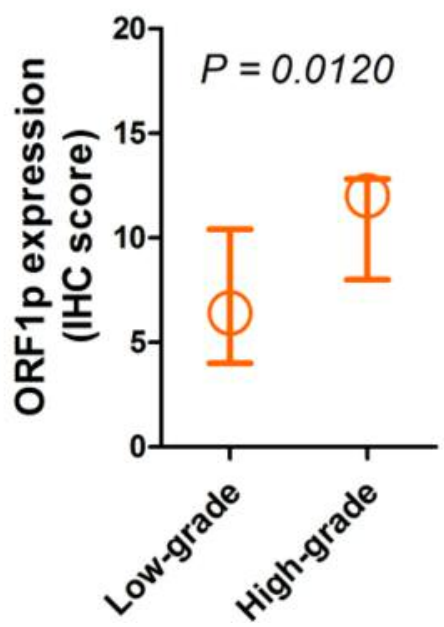

Figure 3. Association of ORF1p expression with bladder tumor progression. ORF1p expression in muscle-invasive bladder tumors was significantly higher than that in papillary/superficial (non muscle-invasive) tumors (A). Likewise, expression of ORF1p in high-grade tumors was significantly higher than low-grade tumors $(B)$. Left: representative immunostainings; right: quantitative evaluation.

in muscle-invasive tumor $(\mathrm{n}=13)$ than in papillary and other non muscle-invasive tumors $(\mathrm{n}=19)(p=0.0397)$ (Figure 3A). Similarly, ORF1p expression in high-grade bladder tumor $(n=18)$ was significantly higher than in low-grade tumors $(n=13)$ (Figure 3B). To quantify the strength of association between ORF1 expression and tumor progression, we categorized ORF1p expression into high (IHC score $\geq 12$ ) and low (IHC score <12) expression. Logistic regression adjusted for patients' age revealed that muscle-invasive bladder tumor tissues were about 6 times more likely to express ORF1p strongly than papillary/non muscle-invasive tumors (Adjusted $\mathrm{OR}=6.15,95 \% \mathrm{CI}: 1.25-30.36, p=0.026)$. Similarly, high- grade bladder tumors were approx. 7 times more likely to express ORF1p strongly than low-grade tumor (Adjusted $\mathrm{OR}=6.73$, 95\% CI: 1.05-42.94, $p=0.044)$. Two tissue samples were histologically classified as PUNLMP, a benign condition. Expression of ORF1p in these PUNLMP samples was relatively low. Collectively, these findings suggest that high expression of ORF1p in bladder tumor tissues is associated with more aggressive tumors.

Despite correlating with ORF1p expression across all samples, 4-HNE levels differed neither significantly between muscle-invasive and papillary/non muscle-invasive tumors nor between low-grade and high-grade tumors. 
A
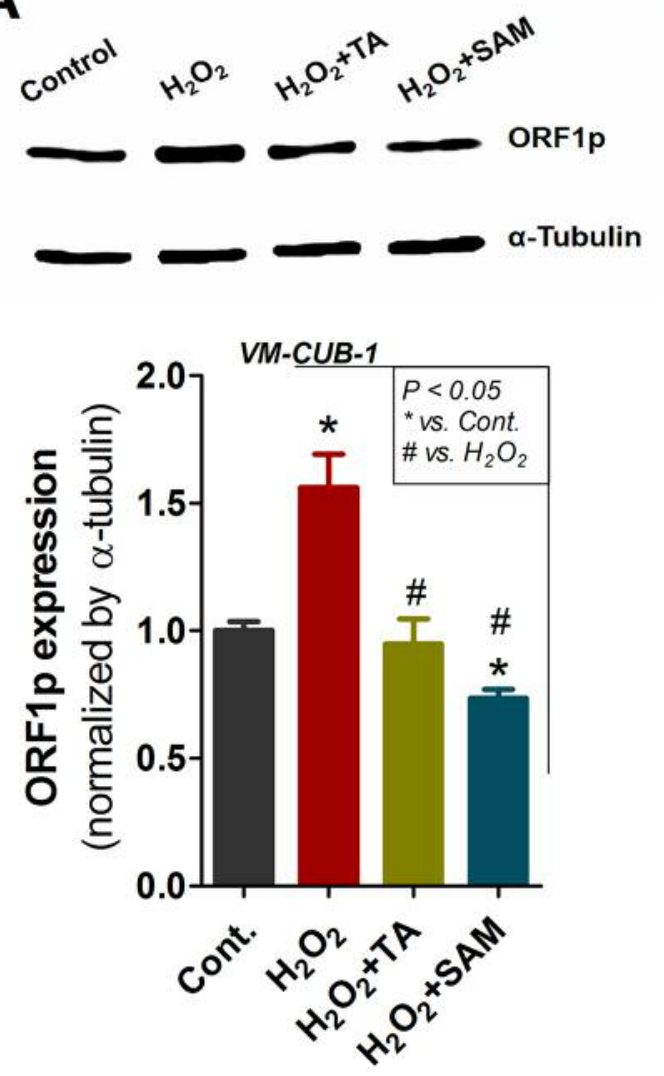

B
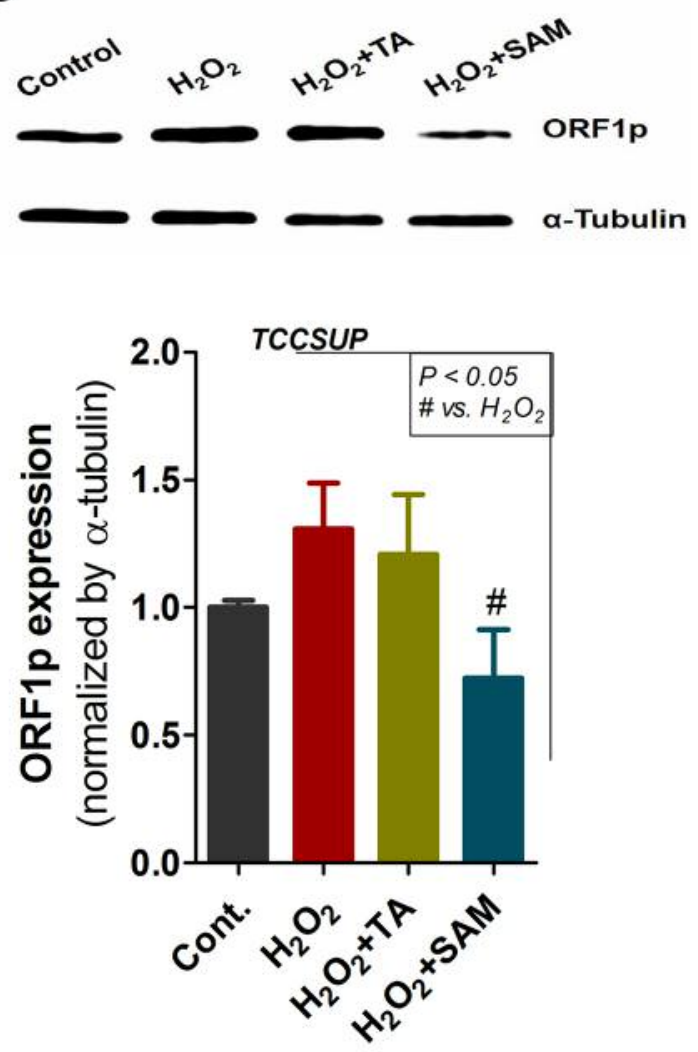

Figure 4. Induction of ORF1p expression by ROS in bladder cancer cell lines. In VM-CUB-1 cells (A), exposure to $\mathrm{H}_{2} \mathrm{O}_{2}(30 \mu \mathrm{M}$ for $72 \mathrm{~h}$ ) caused a significant increase in ORF1p expression compared to untreated controls, and this increment was effectively normalized by co-treatment with antioxidants (for $72 \mathrm{~h}), \mathrm{TA}(300 \mu \mathrm{M})$ and SAM $(100 \mu \mathrm{M})$. In TCCSUP cells $(\mathrm{B})$, ORF1p expression was slightly increased after $\mathrm{H}_{2} \mathrm{O}_{2}$ exposure without reaching statistical significance. Co-treatment with SAM significantly caused reduction of ORF1p expression in $\mathrm{H}_{2} \mathrm{O}_{2}$-treated cells.

Effects of oxidative stress on ORF1p expression in bladder cancer cell lines. As a positive correlation between 4-HNE and ORF1p expression in bladder cancer tissues was observed, we further tested whether ROS induced expression of ORF1p in bladder cancer cell lines. Three cell lines were used with different levels of ORF1p expression under control conditions (without $\mathrm{H}_{2} \mathrm{O}_{2}$ ), i.e. strong expression in VM-CUB-1, intermediate expression in TCCSUP, and undetectable expression of ORF1p in UM-UC-3. After $72 \mathrm{~h} \mathrm{H}_{2} \mathrm{O}_{2}$ treatment, expression of ORF1p in VM-CUB-1 was significantly increased compared with the untreated control (Figure 4A). This increase was abolished by co-treatment with antioxidants (TA and SAM). In TCCSUP, a similar tendency for changes in ORF1p expression under each treatment was found as in VM-CUB-1, but the increase in ORF1p expression in the $\mathrm{H}_{2} \mathrm{O}_{2}$ treated condition was not statistically significant (Figure 4B). A significant decrease in ORF1p expression in $\mathrm{H}_{2} \mathrm{O}_{2}$-treated condition was only observed in the co-treatment with SAM. $\mathrm{H}_{2} \mathrm{O}_{2}$ did not activate de novo expression of ORF1p in UM-UC-3 cells. Based on these findings, we conclude that ROS significantly enhanced expression of ORF1p only in bladder cancer cells that already had high expression of ORF1p (seen in VM-CUB-1 cells).

ROS induced bladder cancer cell migration. We further asked whether ROS promoted motility of the bladder cancer cell lines, UM-UC-3, TCCSUP and VM-CUB-1. In scratch assays, cells treated with $\mathrm{H}_{2} \mathrm{O}_{2}$ had a higher capability to fill the wounded gap in all cell lines (Figure 5). Accordingly, cotreatment with antioxidant TA retarded the migration of $\mathrm{H}_{2} \mathrm{O}_{2}$ treated bladder cancer cells. This data fits with the idea that oxidative stress provoked by ROS enhances cell properties facilitating tumor aggressiveness (19).

\section{Discussion}

LINE-1-encoded proteins, ORF1p and ORF2p, are thought to have tumorigenic function (20). ROS are overwhelmingly generated in solid tumors causing oxidative stress in the microenvironment that further promotes tumor progression (21, 


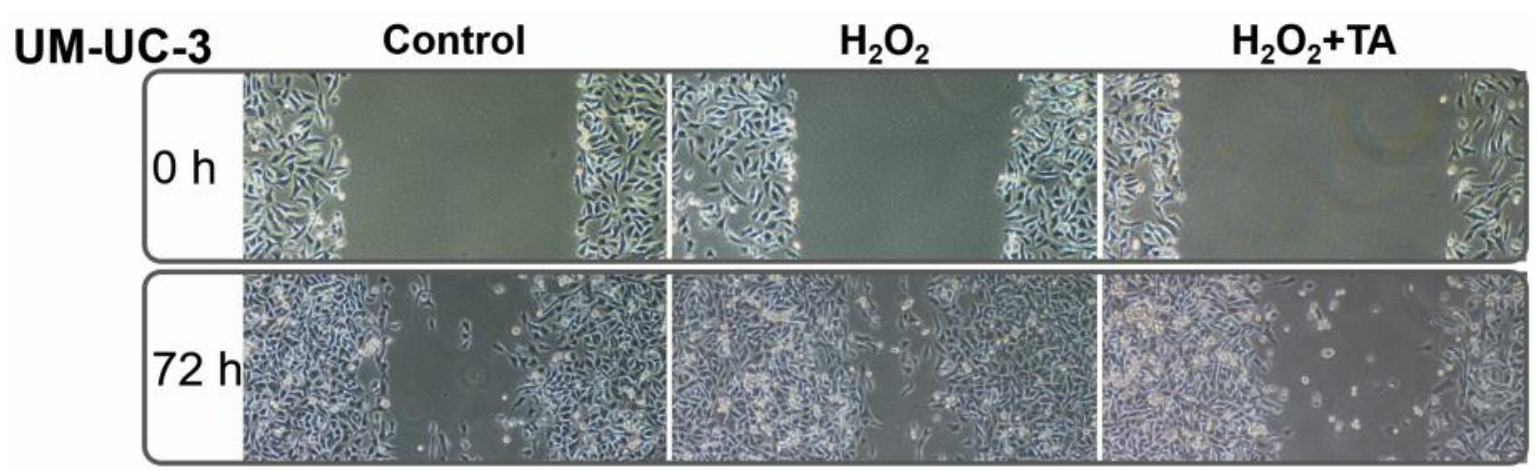

TCCSUP

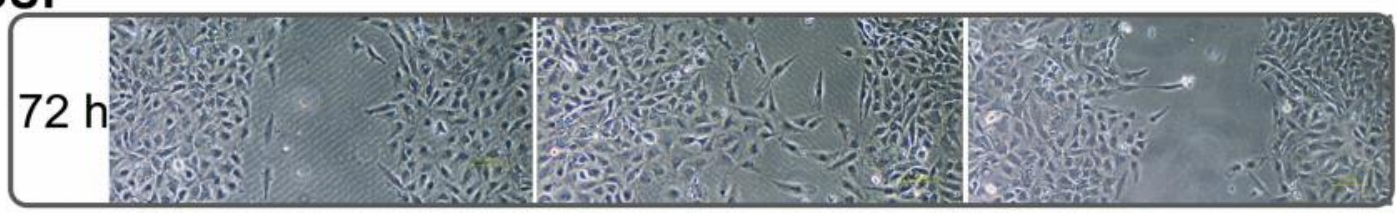

VM-CUB-1

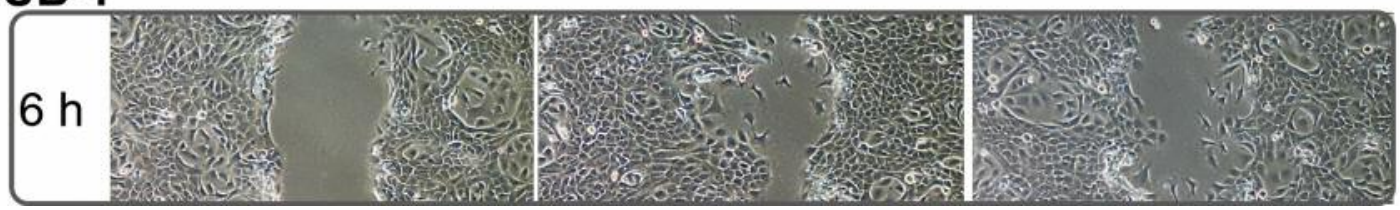

Figure 5. Scratch assay showing ROS-induced cell migration in bladder cancer cell lines, UM-UC-3, TCCSUP and VM-CUB-1. UM-UC-3 and TCCSUP were treated with $\mathrm{H}_{2} \mathrm{O}_{2}$ for $72 \mathrm{~h}$, but VM-CUB-1 for $6 \mathrm{~h}$. All $\mathrm{H}_{2} \mathrm{O}_{2}$-treated cells migrated faster to fill the gaps than the untreated control cells. Co-treatment with TA reduced the migration capability of the $\mathrm{H}_{2} \mathrm{O}_{2}$-treated cells.

22). In this study, we found an increased ORF1p expression in human bladder cancer tissues compared to adjacent noncancerous tissues. Expression of ORF1p in bladder cancer tissues was linearly correlated with 4-HNE expression. Importantly, elevated ORF1p expression was associated with muscle-invasive and high-grade tumors. Experimentally, ROS caused rise of ORF1p expression in VM-CUB-1, a cell line of muscle-invasive origin. Additionally, ROS was capable of increasing cell migration activity in bladder cancer cells.

Whereas LINE-1 DNA hypomethylation is well recognized in bladder cancer, data on the expression of full-length LINE-1, which are exclusively responsible for retrotransposition and genetic instability, are still scarce. An increased transcript expression of full-length LINE-1 in bladder tumor tissues compared to the benign tissues was demonstrated (23). ORF1p expression in bladder carcinoma tissues was firstly reported by Rodic et al. (8). In a survey of various cancer types, they found immunoreactivity of ORF1p in about $61 \%$ of tissue samples. In the present study specifically on bladder cancer, ORF1p was broadly and strongly expressed in cancer tissues with only 3 out of $36(8.3 \%)$ sections negative for ORF1p. Moreover, the intensity of ORF1p staining increased with stage and grade suggesting that ORF1p expression is associated with tumor progression. Our findings corroborate the reactivation of intact LINE-1 elements in bladder cancer, and suggest that its detection could be applied clinically as an indicator of tumor progression.

Whereas almost all LINE-1 copies have no intact ORFs and can be considered as molecular fossils, a small number of intact LINE-1, called human-specific LINE-1 subfamily or L1HS-Ta, can become active and account for retrotransposition and genome plasticity in human evolution and disease $(2,24,25)$. Furthermore, activation of individual LINE-1 in somatic cells appears to be cell-type dependent (26). Accordingly, specific L1HS-Ta elements tend to become hypomethylated in bladder cancer (27). However, it is not known yet which specific LINE-1 loci are permissive for transcriptional reactivation in bladder cancer. Identifying these elements might help to pave the way towards using LINE-1 proteins as specific biomarkers in bladder cancer.

We previously reported increased oxidative stress and DNA hypomethylation of LINE-1 in bladder cancer tissues, and experimentally showed that ROS caused hypomethylation of LINE-1 (14-16). In this study, we investigated whether ROSinduced LINE-1 DNA hypomethylation might lead to upregulation of LINE-1-encoded protein in bladder cancer 
cells. Interestingly, a significant upregulation of ORF1p by ROS (approx. 1.6 fold) was observed only in VM-CUB-1. In TCCSUP, the increase was lower (approx. 1.3 fold) and none was observed in UM-UC-3. This difference may relate to the degree of LINE-1 hypomethylation overall as well as to that at individual active loci, which may differ between the cell lines. DNA methylation level of LINE-1 is about two times lower in VM-CUB-1 than in UM-UC-3, and intermediate in TCCSUP $(15,23)$. We hypothesize that reactivation of LINE1 protein expression mediated through DNA hypomethylation is initiated when the level of DNA methylation at individual LINE-1 loci is low enough to reach a threshold allowing transcriptional reactivation. Once reactivated, ROS generated in the tumor cells further enhances ORF1p expression and subsequently promotes tumor progression.

In additional experiments we showed that migration activity of bladder cancer cells was induced by ROS highlighting another mechanism through which ROS could promote tumor progression $(28,29)$. Recently, we demonstrated ROS-induced cell migration and invasion in hepatocellular carcinoma (18). Clearly, further experiments are warranted to define to which extent ROS-induced tumor progression involves oncogenic functions of LINE-1 proteins.

Limitations of the present study should be mentioned as well. The sample size for an IHC study was relatively small. However, significant difference between cancerous and noncancerous areas and clinical association of ORF1p were observed, suggesting a promising clinical potential of this protein. In this study cells were exposed to a non-toxic dose of $\mathrm{H}_{2} \mathrm{O}_{2}$ for 3 days. However, some oxidative stress-induced epigenetic changes may require much longer exposures, perhaps up to 6 months (30). It is interesting to see further whether a long-term exposure to $\mathrm{H}_{2} \mathrm{O}_{2}$ is able to significantly reactivate the LINE- 1 elements in TCCSUP and UM-UC-3.

In conclusion, we presented robust evidence for reactivated ORF1p and increased oxidative stress in human bladder cancer tissues. ORF1p and 4-HNE expression were positively correlated. Elevated ORF1p was associated with muscle-invasive as well as high-grade tumors. To our knowledge, this study is the second study showing an anincreased ORF1p expression in bladder cancer tissues, but the first demonstrating an association of elevated ORF1p expression with oxidative stress and bladder tumor progression and showing an induction of ORF1p expression by ROS in bladder cancer cells. As a therapeutic application, diminution of oxidative stress might be helpful for preventing LINE-1 reactivation and decelerating progression of bladder tumors.

\section{Conflicts of Interest}

The Authors declare that they have no competing interests.

\section{Funding}

The study was supported by Thailand Research Fund and Chulalongkorn University (RSA5680019 to C.B.). P.W. was awarded The 90th Anniversary of Chulalongkorn University Scholarship and the DPST scholarship. Partially supported by the Ratchapiseksompotch Fund, Faculty of Medicine, Chulalongkorn University (RA57/118 to C.B.). C.B. was awarded a renewed research stay in Germany (2016) by the Alexander von Humboldt Foundation.

\section{Acknowledgements}

The Authors would like to thank to Christiane Hader, Surasit Suwannasin, Chakriwong Ma-on and Suchittra Phoyen for excellent assistance.

\section{References}

1 Lander ES, Linton LM, Birren B, Nusbaum C, Zody MC, Baldwin J, Devon K, Dewar K, Doyle M, FitzHugh W, Funke R, Gage D, Harris K, Heaford A, Howland J, Kann L, Lehoczky J, LeVine R, McEwan P, McKernan K, Meldrim J, Mesirov JP, Miranda C, Morris W, Naylor J, Raymond C, Rosetti M, Santos R, Sheridan A, Sougnez C, Stange-Thomann Y, Stojanovic N, Subramanian A, Wyman D, Rogers J, Sulston J, Ainscough R, Beck S, Bentley D, Burton J, Clee C, Carter N, Coulson A, Deadman R, Deloukas P, Dunham A, Dunham I, Durbin R, French L, Grafham D, Gregory S, Hubbard T, Humphray S, Hunt A, Jones M, Lloyd C, McMurray A, Matthews L, Mercer S, Milne S, Mullikin JC, Mungall A, Plumb R, Ross M, Shownkeen R, Sims S, Waterston RH, Wilson RK, Hillier LW, McPherson JD, Marra MA, Mardis ER, Fulton LA, Chinwalla AT, Pepin KH, Gish WR, Chissoe SL, Wendl MC, Delehaunty KD, Miner TL, Delehaunty A, Kramer JB, Cook LL, Fulton RS, Johnson DL, Minx PJ, Clifton SW, Hawkins T, Branscomb E, Predki P, Richardson P, Wenning S, Slezak T, Doggett N, Cheng JF, Olsen A, Lucas S, Elkin C, Uberbacher E, Frazier M, Gibbs RA, Muzny DM, Scherer SE, Bouck JB, Sodergren EJ, Worley KC, Rives CM, Gorrell JH, Metzker ML, Naylor SL, Kucherlapati RS, Nelson DL, Weinstock GM, Sakaki Y, Fujiyama A, Hattori M, Yada T, Toyoda A, Itoh T, Kawagoe C, Watanabe H, Totoki Y, Taylor T, Weissenbach J, Heilig R, Saurin W, Artiguenave F, Brottier P, Bruls T, Pelletier E, Robert C, Wincker P, Smith DR, Doucette-Stamm L, Rubenfield M, Weinstock K, Lee HM, Dubois J, Rosenthal A, Platzer M, Nyakatura G, Taudien S, Rump A, Yang H, Yu J, Wang J, Huang G, Gu J, Hood L, Rowen L, Madan A, Qin S, Davis RW, Federspiel NA, Abola AP, Proctor MJ, Myers RM, Schmutz J, Dickson M, Grimwood J, Cox DR, Olson MV, Kaul R, Raymond C, Shimizu N, Kawasaki K, Minoshima S, Evans GA, Athanasiou M, Schultz R, Roe BA, Chen F, Pan H, Ramser J, Lehrach H, Reinhardt R, McCombie WR, de la Bastide M, Dedhia N, Blocker H, Hornischer K, Nordsiek G, Agarwala R, Aravind L, Bailey JA, Bateman A, Batzoglou S, Birney E, Bork P, Brown DG, Burge CB, Cerutti L, Chen HC, Church D, Clamp M, Copley RR, Doerks T, Eddy SR, Eichler EE, Furey TS, Galagan J, Gilbert JG, Harmon C, Hayashizaki Y, Haussler D, Hermjakob H, Hokamp K, Jang W, Johnson LS, Jones TA, Kasif S, Kaspryzk A, Kennedy S, Kent WJ, Kitts P, Koonin EV, Korf I, Kulp D, Lancet D, Lowe TM, McLysaght A, Mikkelsen T, Moran JV, Mulder N, Pollara VJ, Ponting CP, Schuler G, Schultz J, Slater G, Smit AF, Stupka E, Szustakowki J, Thierry-Mieg D, Thierry-Mieg J, Wagner L, Wallis 
J, Wheeler R, Williams A, Wolf YI, Wolfe KH, Yang SP, Yeh RF, Collins F, Guyer MS, Peterson J, Felsenfeld A, Wetterstrand KA, Patrinos A, Morgan MJ, de Jong P, Catanese JJ, Osoegawa K, Shizuya H, Choi S, Chen YJ, Szustakowki J and International Human Genome Sequencing C: Initial sequencing and analysis of the human genome. Nature 409: 860-921, 2001.

2 Brouha B, Schustak J, Badge RM, Lutz-Prigge S, Farley AH, Moran JV and Kazazian HH, Jr: Hot L1s account for the bulk of retrotransposition in the human population. Proc Natl Acad Sci USA 100: 5280-5285, 2003.

3 Beck CR, Collier P, Macfarlane C, Malig M, Kidd JM, Eichler EE, Badge RM and Moran JV: LINE-1 retrotransposition activity in human genomes. Cell 141: 1159-1170, 2010.

4 Doucet-O'Hare TT, Rodic N, Sharma R, Darbari I, Abril G, Choi JA, Young Ahn J, Cheng Y, Anders RA, Burns KH, Meltzer SJ and Kazazian HH Jr.: LINE-1 expression and retrotransposition in Barrett's esophagus and esophageal carcinoma. Proc Natl Acad Sci USA 112: E4894-4900, 2015.

5 Rodic N and Burns KH: Long interspersed element-1 (LINE-1): passenger or driver in human neoplasms? PLoS Genet 9: e1003402, 2013.

6 Taylor MS, LaCava J, Mita P, Molloy KR, Huang CR, Li D, Adney EM, Jiang H, Burns KH, Chait BT, Rout MP, Boeke JD and Dai L: Affinity proteomics reveals human host factors implicated in discrete stages of LINE-1 retrotransposition. Cell 155: 1034-1048, 2013.

7 Ardeljan D, Taylor MS, Ting DT and Burns KH: The human long interspersed element-1 retrotransposon: An emerging biomarker of neoplasia. Clin Chem 63: 816-822, 2017.

8 Rodic N, Sharma R, Sharma R, Zampella J, Dai L, Taylor MS, Hruban RH, Iacobuzio-Donahue CA, Maitra A, Torbenson MS, Goggins M, Shih Ie M, Duffield AS, Montgomery EA, Gabrielson E, Netto GJ, Lotan TL, De Marzo AM, Westra W, Binder ZA, Orr BA, Gallia GL, Eberhart CG, Boeke JD, Harris $\mathrm{CR}$ and Burns $\mathrm{KH}$ : Long interspersed element-1 protein expression is a hallmark of many human cancers. Am J Pathol 184: 1280-1286, 2014.

9 Kitkumthorn $\mathrm{N}$ and Mutirangura A: Long interspersed nuclear element-1 hypomethylation in cancer: biology and clinical applications. Clin Epigenetics 2: 315-330, 2011.

10 Falso MJ, Buchholz BA and White RW: Stem-like cells in bladder cancer cell lines with differential sensitivity to cisplatin. Anticancer Res 32: 733-738, 2012.

11 Jurgens B, Schmitz-Drager BJ and Schulz WA: Hypomethylation of L1 LINE sequences prevailing in human urothelial carcinoma. Cancer Res 56: 5698-5703, 1996.

12 Florl AR, Lower R, Schmitz-Drager BJ and Schulz WA: DNA methylation and expression of LINE-1 and HERV-K provirus sequences in urothelial and renal cell carcinomas. Br J Cancer 80: 1312-1321, 1999.

13 Chalitchagorn K, Shuangshoti S, Hourpai N, Kongruttanachok N, Tangkijvanich P, Thong-ngam D, Voravud N, Sriuranpong V and Mutirangura A: Distinctive pattern of LINE-1 methylation level in normal tissues and the association with carcinogenesis. Oncogene 23: 8841-8846, 2004.

14 Patchsung M, Boonla C, Amnattrakul P, Dissayabutra T, Mutirangura A and Tosukhowong P: Long interspersed nuclear element-1 hypomethylation and oxidative stress: correlation and bladder cancer diagnostic potential. PLoS One 7: e37009, 2012.

15 Kloypan C, Srisa-art M, Mutirangura A and Boonla C: LINE-1 hypomethylation induced by reactive oxygen species is mediated via depletion of S-adenosylmethionine. Cell Biochem Funct 33: 375-385, 2015.
16 Wongpaiboonwattana W, Tosukhowong P, Dissayabutra T, Mutirangura $\mathrm{A}$ and Boonla $\mathrm{C}$ : Oxidative stress induces hypomethylation of LINE-1 and hypermethylation of the RUNX3 promoter in a bladder cancer cell line. Asian Pac J Cancer Prev 14: 3773-3778, 2013.

17 Evans PJ, Whiteman M, Tredger JM and Halliwell B: Antioxidant properties of S-adenosyl-L-methionine: a proposed addition to organ storage fluids. Free Radic Biol Med 23: 1002-1008, 1997.

18 Ma-On C, Sanpavat A, Whongsiri P, Suwannasin S, Hirankarn $\mathrm{N}$, Tangkijvanich $\mathrm{P}$ and Boonla C: Oxidative stress indicated by elevated expression of $\mathrm{Nrf} 2$ and $8-\mathrm{OHdG}$ promotes hepatocellular carcinoma progression. Med Oncol 34: 57, 2017.

19 Sesti F, Tsitsilonis OE, Kotsinas A and Trougakos IP: Oxidative stress-mediated biomolecular damage and inflammation in tumorigenesis. In Vivo 26: 395-402, 2012.

20 Xiao-Jie L, Hui-Ying X, Qi X, Jiang X and Shi-Jie M: LINE-1 in cancer: multifaceted functions and potential clinical implications. Genet Med 18: 431-439, 2016.

21 Fiaschi $\mathrm{T}$ and Chiarugi $\mathrm{P}$ : Oxidative stress, tumor microenvironment, and metabolic reprogramming: a diabolic liaison. Int J Cell Biol 2012: 762825, 2012.

22 Carini F, Mazzola M, Rappa F, Jurjus A, Geagea AG, Al Kattar S, Bou-Assi T, Jurjus R, Damiani P, Leone A and Tomasello G: Colorectal carcinogenesis: Role of oxidative stress and antioxidants. Anticancer Res 37: 4759-4766, 2017.

23 Kreimer U, Schulz WA, Koch A, Niegisch G and Goering W: HERV-K and LINE-1 DNA methylation and reexpression in urothelial carcinoma. Front Oncol 3: 255, 2013.

24 Boissinot S, Chevret $\mathrm{P}$ and Furano AV: L1 (LINE-1) retrotransposon evolution and amplification in recent human history. Mol Biol Evol 17: 915-928, 2000.

25 Sassaman DM, Dombroski BA, Moran JV, Kimberland ML, Naas TP, DeBerardinis RJ, Gabriel A, Swergold GD and Kazazian HH Jr.: Many human L1 elements are capable of retrotransposition. Nat Genet 16: 37-43, 1997.

26 Philippe C, Vargas-Landin DB, Doucet AJ, van Essen D, VeraOtarola J, Kuciak M, Corbin A, Nigumann P and Cristofari G: Activation of individual L1 retrotransposon instances is restricted to cell-type dependent permissive loci. Elife 5: e13926, 2016.

27 Nusgen N, Goering W, Dauksa A, Biswas A, Jamil MA, Dimitriou I, Sharma A, Singer H, Fimmers R, Frohlich H, Oldenburg J, Gulbinas A, Schulz WA and El-Maarri O: Inter-locus as well as intra-locus heterogeneity in LINE-1 promoter methylation in common human cancers suggests selective demethylation pressure at specific CpGs. Clin Epigenetics 7: 17, 2015.

28 Liou GY and Storz P: Reactive oxygen species in cancer. Free Radic Res 44: 479-496, 2010.

29 Panieri E and Santoro MM: ROS homeostasis and metabolism: a dangerous liason in cancer cells. Cell Death Dis 7: e2253, 2016.

30 Mahalingaiah PK, Ponnusamy L and Singh KP: Oxidative stressinduced epigenetic changes associated with malignant transformation of human kidney epithelial cells. Oncotarget 8 : 11127-11143, 2017.
Received November 9, 2017

Revised January 23, 2018

Accepted February 1, 2018 